London, UK

Jo.Best@journalist.com

Cite this as: BMJ 2021;374:n1858 http://dx.doi.org/10.1136/bmj.n1858 Published: 29 July 2021
WORKFORCE WELLBEING

\section{Undermined and undervalued: how the pandemic exacerbated moral injury and burnout in the NHS}

\section{Government and employers must assess risk and ensure sufficient personnel, resources, and support to protect NHS staff, an informal inquiry has heard. Jo Best reports}

Jo Best

“I can't describe to you how desperate it was. Every single day there was an NHS worker in tears in the changing room because we were seeing colleagues dying," said Michelle Dawson, an NHS consultant anaesthetist in Derbyshire, recalling the beginning of the pandemic. She was giving evidence to an ongoing informal inquiry into covid-19 in the UK. "We saw them dying and we were terrified we would be next. But you just have to keep going."

Chidi Ejimofo, a London based emergency medicine consultant, described exhaustion among staff in his department. Early in the pandemic they had to create their own guidance for managing covid-19 and buy their own personal protective equipment (PPE). There were insufficient staff because they were falling sick, he said. And, of course, there was the underlying fear. By the second wave, after nine months, staff were exhausted, he told the inquiry. "Junior doctors and nurses had seen things that they shouldn't have been expected to take on at that stage in their training."

Stories of stress and mental health problems because of work are nothing new for NHS staff. But the pandemic has led to increased recognition of "burnout"-the emotional, physical, and mental exhaustion caused by excessive and prolonged stress-and "moral injury"-when professionals are forced to act against their conscience. ${ }^{12}$

\section{The People's Inquiry}

Despite broad and longstanding support for starting a formal review quickly, in May Prime Minister Boris Johnson said that a public inquiry would begin in spring 2022. But delay could mean that opportunities to learn vital lessons are missed, leading to more deaths and harm to the public and key workers, critics say.

For this reason, the campaigning group Keep Our NHS Public convened the People's Covid Inquiry, chaired by the human rights lawyer Michael Mansfield QC. Over nine sessions it gathered evidence from some 40 expert witnesses, key workers, patients, and bereaved people ${ }^{3}$ and recently published interim recommendations. ${ }^{4}$

Testimony described rises in reported burnout and reduced feelings of wellbeing and resilience. The panel heard repeatedly how staff felt undermined and undervalued when, having put their lives at risk to work through the pandemic, the government offered them a $1 \%$ pay rise. Moral injury wasn't intended to be considered by the inquiry but witnesses mentioned it repeatedly.

The inquiry panel had "all been shaken by how bad it is," said Mansfield. "It's moral injury caused by the fact that they've been put into a situation not of their choosing."

\section{Losing the drive to keep working}

A BMA survey with 6126 respondents in April 2020 found that more than $40 \%$ of doctors were experiencing depression, anxiety, stress, or burnout that had been worsened by the pandemic; $60 \%$ reported more fatigue or exhaustion than normal. ${ }^{5}$

"For people to leave home every day to do hard and dangerous work, they need to know that it's worth it, that it means something," Rachel Sumner, senior lecturer in psychology at the University of Gloucestershire, told the inquiry. "We have witnessed that meaning in life is going down," she said, with healthcare workers feeling hopeless and losing the drive to keep working.

Sumner is researching wellbeing, resilience, and burnout among key workers in the UK and Ireland. ${ }^{6}$ Levels of exhaustion, cynicism, and feelings of inadequacy reported by frontline staff had all risen significantly six months into the pandemic, she told The BMJ, and by 12 months levels remained high.

"This was all being driven by the perceived timeliness of the government's actions," Sumner told the inquiry. Metrics in Ireland, where the government's response was seen as more timely, were better than in the UK, she said. UK workers tended to find universities, and pubs were open when they shouldn't have been; and believed rule breaking wasn't dealt with consistently.

Stephen Reicher, professor of social psychology at the University of St Andrews and member of the Independent Scientific Pandemic Insights Group on Behaviours, which advises the independent government advisers the Scientific Advisory Group for Emergencies (Sage) on behavioural science, told the inquiry that burnout is not simply from overwork: feeling unable to do your job properly, however hard you work, also contributes.

Healthcare workers feel undermined, including by the policies that led to covid patient numbers spiking, he said. Other witnesses criticised the government's subsidised Eat Out to Help Out scheme to encourage government messaging unclear; thought that schools, 
people back into restaurants last summer. Reicher also mentioned having to choose between allocating beds to patients with covid or other urgent needs, such as cancer care, and the government's 1\% pay offer. All of this is "deeply demoralising, and leads to profound burnout," he said.

\section{Dangerous and difficult environments}

Eight out of 10 doctors said they have experienced moral injury during the pandemic, in a UK survey run by the BMA from 18 March to 12 April 2021, which received 1933 responses. ${ }^{7}$

The pandemic may have contributed to moral injury in several ways, the inquiry heard. Doctors often found themselves in dangerous and difficult working environments, with unprecedented demands and huge responsibility without the control needed to achieve expected standards of care.

Instead, levels of care decreased as routine operations were suspended and one-to-one care for patients with covid was abandoned, for example. Doctors had to work outside their specialties and lack of PPE meant staff risked infecting patients or turning them away.

Dawson described to the inquiry a hospital at the height of the first wave that had run out of PPE. "When people have died they need to be moved. Porters, who are usually on zero hours contracts, were having to move infected bodies with no body bag, no mask, and no gown," she said. In the first wave, doctors were told that PPE was being redirected to intensive care, and other departments could use it only for staff coming within two metres of patients, Dawson added.

Rachel Clarke, a consultant in palliative care medicine based in Oxfordshire, said that faced with dwindling stocks of PPE, her hospice faced having to redirect dying patients to emergency departments.

"I looked at my medical director and actually started to cry, because we couldn't see any way of protecting our profoundly vulnerable patients, people who deserved to be cared for with enormous dignity," Clarke told the inquiry.

\section{Solutions to systemic problems}

Burnout and moral injury did not begin with the pandemic and will not end with it. "People who have worked in the NHS for a long time have found that they cannot do the job that they wanted to because of austerity, short staffing, and all the rest of it. On top of chronic moral injury, we've now got acute moral injury," said panellist Jacky Davis, a consultant radiologist in London.

Clinical sister Kirsty Brewerton, based in the West Midlands, described to the inquiry working in an emergency department before the pandemic, with too many patients, not enough staff, and feeling nothing was being done to help. "I was forced to work in unsafe conditions, and I ended up having a mental breakdown and becoming suicidal. It's the moral injury of feeling unable to look after people properly.

"If you care about your job, then you want to do it well. You go into this job because you care about people and you want to make them better. When you're forced into a situation where you're unable to do that, or to do your job to the level that you trained at, that is really hard mentally."

"There is a duty of care for the NHS and trusts to recognise we are at risk," she said. "For it not to be a priority is worrying." Mental health support varies across NHS trusts, with no standard risk assessment for workers. Staff aren't trained to maintain their own mental health, Brewerton said. "If we want to retain staff, it's something that should be tackled seriously by all trusts."

Ejimofo called for robust ways for staff to report when they feel that they are constrained from being able to carry out their duties. "That was lacking during this pandemic," he said.

\section{Repair the context}

All this is likely to affect staff retention. The inquiry heard that departures will magnify pressure on the NHS workforce, making it harder to provide the care that patients expect and healthcare workers value, exacerbating future risks of moral injury and burnout.

The inquiry is expected to publish its final report and recommendations in the autumn.

Tony O'Sullivan, a retired paediatrician and co-chair of Keep Our NHS Public, told The BMJ, that the onus must be on government to ensure that healthcare and social care staff have the psychological support they need. "They also need to repair the context in which people are being overworked and demoralised," he said. "It's a political answer: the government has to recognise how its public workforce has suffered and say, 'We will put our faith back in you by funding you properly, by training enough staff, by paying a reasonable wage, and by giving you the equipment, the buildings, and the wards that we've taken away during the past 10 years."”

Commissioning and peer review: Commissioned; not externally peer reviewed.

Competing interests: I have read and understood BMJ policy on declaration of interests and have no relevant interests to declare.

1 Shale S. Moral injury and the covid-19 pandemic: reframing what it is, who it affects and how care leaders can manage it. BMJ Leader. 2020;4:224-7doi: 10.1136/leader-2020-000295

2 Greenberg N, Docherty M, Gnanapragasam S, Wessely S. Managing mental health challenges faced by healthcare workers during covid-19 pandemic. BMJ 2020;368:m1211. doi: 10.1136/bmj.m1211 pmid: 32217624

3 Hurley R. Sixty seconds on ... a covid-19 inquiry. BMJ2021;373:n952. doi: 10.1136/bmj.n952 pmid: 33846114

$4 \quad$ Hurley R. Covid-19: Billions spent on private contracts should have gone to public services, says people's inquiry. BMJ2021;374:n1750. doi: 10.1136/bmj.n1750 pmid: 34244171

5 BMA. Almost half of UK doctors suffering from burnout, depression or anxiety, BMA survey reveals. 19 April 2020. www.bma.org.uk/bma-media-centre/almost-half-of-uk-doctors-sufferingfrom-burnout-depression-or-anxiety-bma-survey-reveals.

6 Sumner RC, Kinsella EL. Grace under pressure: resilience, burnout, and wellbeing in frontline workers in the United Kingdom and Republic of Ireland during the SARS-CoV-2 pandemic. Front Psychol 2021;11:576229. doi: 10.3389/fpsyg.2020.576229 pmid: 33584412

7 Rimmer A. Covid-19: Eight in 10 doctors have experienced moral distress during pandemic, BMA survey finds. BMJ2021;373:n1543. doi: 10.1136/bmj.n1543 pmid: 34135019

This article is made freely available for use in accordance with BMJ's website terms and conditions for the duration of the covid-19 pandemic or until otherwise determined by BMJ. You may use, download and print the article for any lawful, non-commercial purpose (including text and data mining) provided that all copyright notices and trade marks are retained. 